\title{
The Face of Dictatorship in George Orwell's Nineteen Eighty-Four, Gabriel Garcia Marquez's The Autumn of the Patriarch, and Mario Vargas Llosa's The Feast of the Goat
}

\author{
https://doi.org/10.33806/ijaes2000.20.2.8 \\ Mohammad Safaei \\ University of Nottingham, Malaysia
}

\begin{abstract}
This essay is an investigation of dictatorship in three novels: George Orwell's Nineteen Eighty-Four, Gabriel Garcia Marquez's The Autumn of the Patriarch and Mario Vargas Llosa's The Feast of the Goat. I initially review the intellectual relation among these authors, their more or less adherence to, or renunciation of, socialist ideology, and their depiction of the horrors of life under dictatorial regimes. To analyse dictatorship, I draw upon Gilles Deleuze and Félix Guattari's concept of faciality as the processes that engender the machine of face. Faciality, as a theory, explains how specific faces emerge as mixed semiotic regimes with despotic and authoritarian traits. I demonstrate that despite their cultural differences, these novels are analogous in their emphasis on the thematic significance of face and the numerous techniques and apparatuses that are deployed within each authoritarian regime for the proliferation of the leader's face. The novels delineate, in more or less comparable ways, how the State tends to suppress the Church or appropriate its functions, how people succumb to a sanctioned version of reality, and how they typically learn to revere a despotic authority that imposes on them the most atrocious rules and practices. The novelists portray not only the suppression of individual freedoms, but also the precariousness of existence under despotic regimes.
\end{abstract}

Keywords: dictatorship, faciality, politics, reality, religion, subjectification

\section{Introduction}

George Orwell's Nineteen Eighty-Four, first published in 1949, envisages "an execrable regime which by the year 1984 has overrun England and indeed the world" (Plank 2007: 83). A prophetic vision of a "dystopia" (Lonoff 2007: 31), the novel was primarily construed as a derisive criticism of socialist governments in the former Soviet Union and its ideological allies across the globe (Sabin 2007: 53). More specifically, not only is the novel an ingenious depiction of how a “dictatorship operates" (Trilling 1975: 260), but it also lays an implicit emphasis on the proclivity of all societies toward some form of "totalitarianism" (Marks 2011: 120). I consider, as such, a comparison of Orwell's narrative with two novels of dictatorship, The Autumn of the Patriarch and The Feast of the Goat, respectively by Gabriel Garcia Marquez and Mario Vargas Llosa, as a critique of how culturally diverse literary works can represent life under dictatorial regimes. To investigate the portrayal of dictatorship in the three novels, I draw upon the multifaceted concept of faciality that Gilles Deleuze and Félix Guattari specifically develop in 
their collaborative work, A Thousand Plateaus: Capitalism and Schizophrenia. Faciality, in brief, implies the social processes that engender 'face' and explains the intersection between two heterogeneous and yet complementary semiotic systems with emerging qualities for the production of signification, subjugation of individuals, suppression of polyvocality, and construction of truth. Although I discuss some of the disparities among the three novels, this essay basically concentrates on the politics of 'face' and those analogous patterns and interactions that explain the operations of faciality, for instance, the proliferation of face, the passional relation between subjects and their despotic leaders, the dictated perception of reality, and the appropriation of the Church or its functions by the State.

Prior to my comparative analysis, I deem it essential to present a concise examination of the nuanced relations among the three authors: a canonical British novelist, on the one hand, and two Nobel Laureates of literature from two different regions of Latin America, on the other. Vargas Llosa esteems Orwell as a grand literary master with a profound lesson: "a literature stripped of morality is inhuman" (Vargas Llosa 2010: 6). Conversely, the relation between Peruvian Vargas Llosa and Colombian Garcia Marquez is more ambivalent, occasioned by a feeling of mutual resentment that at times undermines the friendship between the two authors (Pelayo 2009: 41). What is remarkable is that all these authors more or less demonstrate, at least for a limited period during their lives, enthusiasm for socialist ideology. George Orwell cherished certain aspects of socialism while he disparaged some others. His adherence to egalitarianism, his discontentment with trivial disputations among leftist intellectuals, his empathy with working classes and, in general, his unconventional socialism "separated him from many of his fellow socialists" (Rossi and Rodden 2007: 4). Both Garcia Marquez and Vargas Llosa were also socialists and among several other Latin American Boom writers who were once galvanized by Fidel Castro and his socialist revolution in Cuba. Nonetheless, if one can encapsulate the political orientation of the Latin American Boom in its faith in the ideals of the Cuban Revolution during 1960s, that faith was gradually undermined by disillusionment (Donoso 1977: 48-50). Although Garcia Marquez's friendship with Castro proved long-lasting, Vargas Llosa's criticism of Castro and his regime's suppression of intellectual dissent, including the imprisonment of Cuban poet Heberto Juan Padilla in 1971, eventually culminated in the Peruvian author's "neoliberal politico-economic reorientation" in the 1980s (Moraña 2016: 16).

Unlike Orwell's dystopian narrative which has also been appraised as a canonical account of anti-communism during the Cold War (Ingle 2006: 2), Garcia Marquez's The Autumn of the Patriarch and Vargas Llosa's The Feast of the Goat are both descendants of the dictator novel, a subgenre in Latin American literature with its own masterpieces such as Reasons of State by Alejo Carpentier and I the Supreme by Augusto Roa Bastos (Boldy 2010: 82). The Autumn of the Patriarch and The Feast of the Goat delineate, to a more or less extent, the genuine experience of dictatorship in Latin American republics. Just as Vargas Llosa's novel revolves around the life and reign of Rafael Leónidas Trujillo Molina (1891-1961), the 
dictator of Dominican Republic and "one of the fiercest men in Latin American history" (Polit-Dueñas 2007: 99), the details of the protagonist's characterization in The Autumn of the Patriarch "suggest that the Patriarch is based on dictators, mainly from central America and the Caribbean, from the late nineteenth century to around 1960" (Boldy 2010: 84). The three novels of this essay have received both acclamation and pungent criticism. Nineteen Eighty-Four is censured for its author's "lack of understanding of the economics of class exploitation" (Ingle 2006: 10). The two Latin American novels are also castigated, for the anonymous narrator, in The Autumn of the Patriarch, "actually commiserates with the despot" instead of denouncing him, and The Feast of the Goat fails to attain the depth of representation by its author's infelicitous "attempt to distance himself from the great landmark works of the Novel of the Dictator" in South America (López-Calvo 2005: 55).

Nineteen Eighty-Four presents a highly bizarre setting: Oceania, a location accommodating British or American populations under a government that is markedly Soviet in its partisan leadership and in its enforcement of laws and rules (R. Williams 2007: 16). The people of Oceania are trained from their childhood to detect evil and to distinguish the demonic from the sacred. Simultaneously, they are deprived from any independent discernment or any historical memory to recognize evil and its manifestations. They are taught instead not only to rely on the ruling party to attain a sense of good versus evil, but also to adore Big Brother and to adhere without any reservations to his contradictory laws. This popular submission to authority and its oxymoronic mottos of "War is Peace, Freedom is Slavery, Ignorance is Strength" is mixed with ideological zeal and religious devotion, evoking "both the obscure, paradoxical language of religious revelation and the oracular pronouncements of dialectical materialism" (Gottlieb 2007: 52-53). The Autumn of the Patriarch is a mythopoeic portrayal of a horrendous dictatorship under an anonymous army general in an unspecified location resembling a Caribbean republic. However, more than being a factually accurate depiction of dictatorship, the novel is concerned with power and its enigma, fragility, and eventual decadence (R. L. Williams 2007: 124-127). Garcia Marquez's novel depicts "the trial of a recently overthrown dictator, to be narrated through monologues around a corpse" (Martin 2008: 240). It intermixes fantasy with reality not only to accord insights into the dynamics of political authority and a despot's obsession with sex and security, but also to extend the magical realist mode of narration to its extremes (Bell 1993: 70-71).

The Feast of the Goat differs substantially from both Nineteen Eighty-Four and Garcia Marquez's enigmatic narration in that it posits a commixture of fiction and veritable facts, revolving around two sets of events and characters: the actual assassination of the Dominican dictator Trujillo, on the one hand, and, on the other, the life of fictitious Urania Cabral, a woman who, almost three decades after the death of Trujillo, returns to the Dominican Republic to visit and censure her extremely sick and old father, former Senator Cabral, "only to relive in her mind the events" that enforced her to leave her homeland (Figueroa 2013: 95). Being renowned as the Chief and also as the Goat because of his untiring spirit and also because of this term's evocation of the idea of the Devil, Trujillo ruled the 
Dominican Republic, either directly or by proxy, for almost three decades until his violent death in May 1961. Having been trained by the US marines, he succeeded to attract the endorsement of successive US government administrations not only by influencing the politicians and the public opinion in the United States, but also by presenting himself as a safeguard against the spread of communism in his country. Through an intricate network of cronies, informers, and thugs, he controlled all institutions of power and "turned the Dominican Republic into his and his grasping family's private fiefdom" (Griffin 2012: 116).

At first glance, an immense disparity exists among the three novels regarding their delineation of dictatorship. Whereas Nineteen Eighty-Four portrays the opposition between a tremendously vulnerable and physically feeble protagonist against an invincible empire of suppression, the two Latin American novels are less pessimistic, as they depict the possibility of dissent and emancipation from decrepit dictators. Nonetheless, the three novels accord crucial as well as homologous insights into abusive political systems. The structure of power in Orwell's narration is significant and, in some measure, it resembles Latin American dictatorships that were operative around mid-twentieth century. Orwell's reference to the demographic structure of power is revealing, for there are Negroes, Jews, and "South Americans of pure Indian blood" among "the highest ranks" of the only political party in Oceania (Orwell 1977: 208-209). More importantly, in no region of Oceania do the people, who are dispossessed of their basic rights, feel "that they are a colonial population ruled from a distant capital" (209). Not only have the people succumbed to one political party and its leader recognized as Big Brother, but they all have adapted English as their "lingua franca" (209). Remarkable in Nineteen Eighty-Four is also the depiction of a despotic face, a ubiquitous as well as "an enormous face, more than a meter wide" (1), with a gaze relentlessly observing every movement of an individual, with posters and billboards reminding the people that "Big Brother is watching you" (2). The explicit and implicit references to face, eyes, and the gaze of a dictator have thematic significance in both The Autumn of the Patriarch and The Feast of the Goat. Garcia Marquez's narrative commences with a macabre scene of the "rotting grandeur" in a fallen seat of political power, recounting how "the vultures" have invaded "the presidential palace by pecking through the screens on the balcony windows" (Garcia Marquez 2014: 1). The incident, enunciating the collapse of a "great man", has awakened the city "out of its lethargy of centuries" (1), and the people are incredulous that a formidable leader might leave a "vulture-ravaged" corpse, with "empty sockets for the eyes" (39).

The Feast of the Goat introduces the readers to the infirmity of Trujillo's body: "His bones ached and he felt pains in his leg and back muscles" (Vargas Llosa 2012: 18). Once capable of buying, intimidating, or exterminating his adversaries, Trujillo is now subdued by his physiological malfunctioning that "lived inside him" and "was destroying him" and "his aura of superiority" (18). The narrator lays an insistence on Trujillo's eyes that blink "in the dark" and on his paralysis "from a sense of catastrophe" (16). Upon his assassination, the dictator's piercing "gaze he used to intimidate people" is ultimately demolished (138), with his "face destroyed" 
(227). Whereas Nineteen Eighty-Four explains the enormity of Big Brother's face and demonstrates how the annihilation of subversive acts entails a macabre threat to the "face" of the dissident figures Winston and Julia (Orwell 1977: 285), The Autumn of the Patriarch and The Feast of the Goat depict the demise of authority by reference to a process of physical decrepitude and the destruction of the dictator's face. Despite these superficial differences, the recurrence of 'face' is a crucial hint at the organization of power that I intend to investigate by drawing upon the concept of faciality.

Face and, consequently, the concept of faciality or visagéité originate from the specific mode of metaphysics that Deleuze and Guattari intend to develop in their distinct philosophies as well as in their collaborative work. Face is an empirical reality, and faciality refers to a real machine of signs that strategically valorises a master signifier and ensures its prevalence. Representing a Eurocentric signifier of domination, faciality enslaves people and imposes on them the law of transcendence. Hence, familiarity with the operation of this machine is a priority for Deleuze and Guattari in explaining how we encounter it, how we may decide to dismantle it, or how we can emancipate ourselves from its Eurocentricity and transcendence (Dosse 2010: 254-255). "The face is a politics" (Deleuze and Guattari 1987: 181) and, as such, it must not be conceived of as a metaphoric representation or a part of human organism but "a structured, spatial organization" of power (Deleuze 2003: 20). 'Face' is the prime constituent of faciality and it explains how people often interpret an utterance by interpreting the face or gaze of their interlocutors. Face is the principal source for the emanation of voice and it determines how we may, for instance, construe an utterance as a friendly request or a threat. In a broader sense, face functions as the centre of any domineering signifying regime (Deleuze and Guattari 1987: 115). Faciality operates as "a systematic framing of all perceptions and all behaviours while determining the strategies of the subjects of desire" (Guattari 2011: 76). Whereas we are able to visualize typical faciality traits for a banker, a psychologist, a clergyman, or a bureaucrat, this essay aims to explore the faciality of the supreme figure of the State. This political figure, in some societies, represents a personality "with a clenched fist but a gentle face, who knows how to keep his subordinates, who are themselves highly important, in their place, and who knows in turn, etc." (Guattari 2016: 49). Not only is the question of faciality and its varied mechanisms in diverse sociopolitical systems a matter of further investigation and conceptualization, but we should also consider that behind the gaze or face of the head of State, there resides the faciality of "the chief of police, that of the boss, the teacher, the father, the gentle superego" (49).

In the following two sections, under 'dictatorship of face' and 'passionalparanoid face', I explore the construction and functions of faciality along with my analysis of several passages and incidents in the selected novels. Under 'dictatorship of face', I discuss the formation of faciality as a regime of signification and identification as well as a machine for the subjectification of people in totalitarian regimes. How an individual is subdued and transformed into a subject is a key function of contemporary dictatorial states and their regimes of face. As 
subjectification involves both a conscious choice as well as a passional relation to a signifier or leader, the section on 'passional-paranoid face' addresses the religious and political components of faciality. This salient aspect of face affords me a solid framework for the analysis of the relation between the Church and the State, between subjects and their despotic leaders, and between subjects and their perception of reality. Finally, Deleuze and Guattari acknowledge the "limited" scope of their approach to signifying regimes (Deleuze and Guattari 1987: 119), emphasizing the non-universality of facial machine and the importance of attention to the yet to be explored disparities among "Indian, African, and Asiatic despotic formations" of signification (182). Hence, the application of their theory of faciality to the selected texts in this paper not only contributes to the development of this concept, which has received meagre attention as a literary theory, but also aims to demonstrate how this theoretical concept can accord insights into the formation of dictatorships and their depiction in both European and non-European literatures.

\section{The dictatorship of face}

The depiction of faciality in the three novels is not, despite their resemblances, symmetrical. Face, Orwell demonstrates, emanates meaning and although some people such as Winston struggle to have an "inscrutable" face, they are simultaneously aware that a "single flicker of the eyes" can betray their intentions (Orwell 1977: 36). This relation, in regard to the question of faciality in Nineteen Eighty-Four, needs to receive more attention, for signification in the novel resonates through a variety of apparatuses, including the Ministry of Truth, a soaring tower with a "white face" on which are elegantly written the tripartite principles of the party: "War is peace; freedom is slavery; ignorance is strength" (4). In Oceania, "the same slogans" are inscribed on one side of all coins, with the other side showing "the head of Big Brother" (26). On the one hand, the contradictory laws propagated by the Party in Nineteen Eighty-Four are representative of diverse facets of the machine of indoctrination and power in dictatorship regimes. On the other hand, we may construe Orwell's novel, apart from being a narrative about constant surveillance of people under a despotic regime, as the account of life under the dictatorship of face. In this respect, the recurrence of 'face' and 'white face' in the novel, from a Deleuzo-Guattarian perspective, becomes tremendously significant.

In reality, 'face' is not a means of recognition or identification but the politics made as a consequence of intersection between the two regimes of signification and subjectification. The former implies a semiotic system, the ground, or the white wall against which we define our subjectivity and interpret a variety of events; the latter, conceived of as a black hole, refers to a regime for the absorption of individuals and their transposition into subjects. Face is, therefore, the intersection of the white wall of signification and the black holes of subjectification. Wherever a face exists, a "white wall/black hole system" is arguably in operation (Deleuze and Guattari 1987: 167). The notion of black hole is significant, as it evokes the concept of black holes in astronomy with their immense gravity, functioning as an apparatus of capture, absorbing anything that enters their gravitational sphere 
(Deleuze and Parnet 2007: 17). A black hole, primarily a scientific term that can equally be employed by artists as well as by philosophers, determines the points of finitude for the subjects (Deleuze 1995: 29). Faciality, as such, functions as a machine for the subjugation of individuals, operating via biunivocalization: "it is a man or a woman, a rich person or a poor one, an adult or a child, a leader or a subject" (Deleuze and Guattari 1987: 177).

Face, as a politics and as a social construction, functions at various levels of signification and subjectification. The face of a father, a teacher, or a boss each has its own semiotic traits. In the three novels, specific facial features are attributed to political leaders, those who oppose them, and those who help them in the solidification of their dominance. Nineteen Eighty-Four demonstrates how the face of archenemy Goldstein is broadcast on telescreens to germinate not only revulsion against the enemy, but also solidarity under a single leadership in Oceania with one ultimate objective: "complete and final elimination of Goldsteinism" (Orwell 1977: 54). Further, Big Brother's enormous face not only gazes down "from every commanding corner" of the city, but "his eyes follow you about when you move" (2). O'Brien, the intelligent inquisitor in Nineteen Eighty-Four, is also recognizable by his "coarse, humorous, brutal face" (10). The dictator in The Autumn of the Patriarch possesses an obtrusive "face twisted in a stupor" that terrifies Brigadier General Rosendo Sacristán (Garcia Marquez 2014: 221). In The Feast of the Goat, Trujillo's "face" and his "piercing and merciless" eyes remind "people who it was who ruled this country and the lives of Dominicans" (Vargas Llosa 2012: 78). He possesses a "gaze that no one could endure without lowering his own eyes" (37). The same horrifying gaze is also attributed to Trujillo's most devoted official Johnny Abbes Garcia, the head of Military Intelligence Service (SIM), a man with "perpetually darting eyes" who relishes reading books about Chinese techniques of torture and execution (72).

Here I have to emphasize a crucial observation in regard to the very idea of 'gaze'. Deleuze and Guattari assert that the philosophy of 'gaze' typically accords a mode of humanity to subjects and their relations. On the contrary, what is at stake is the "inhumanity of the face" (Deleuze and Guattari 1987: 181), for "gaze is but secondary in relation to the gazeless eyes, to the black hole of faciality" (171, emphasis original). Gaze, in other words, defines the way a dictatorship functions. When Winston contemplates on the portrait of Big Brother in a children's history book, he is mesmerized by Big Brother's "hypnotic eyes" that "penetrated inside your skull, battering against your brain, frightening you out of your beliefs, persuading you, almost, to deny the evidence of your senses" (Orwell 1977: 80). In The Feast of the Goat, the inhumanity of face is substantially reflected in the atrocious practices against those who are, for one reason or another, disfavoured by Trujillo. Not only is Senator Cabral well aware that "nobody would dare" accuse him overtly of misconduct "without Trujillo's authorization" (Vargas Llosa 2012: 232), but the allusion to The Trial by Orson Welles, a 1962 filmic rendition of Franz Kafka's novel, reassures that a subject, under a despotic face, is interminably endangered by the threat of being "tried and executed" without knowing the exact nature of his crime (233). More remarkable is that both Vargas Llosa and Garcia 
Marquez demonstrate that what fascinates the dictators is the extent to which they admire the face of the others. Trujillo, as such, is curious to see the "face" of Antonio de la Maza, for not only does he daringly wage war on the military strongman "for almost three years" (91), but he also, once imprisoned, persuades his family not to entreat Trujillo's "clemency" (91). Similarly, the patriarch, in Garcia Marquez's novel, admires the crafty and cruel José Ignacio Saenz de la Barra by alluding to his "indestructible face" (Garcia Marquez 2014: 176). In Nineteen Eighty-Four, Winston eventually surrenders to the threat of exposing his face to a throng of starving "carnivorous" rats (Orwell 1977: 285), with this enforced submission implying that what intrigues O'Brien is the face of those who dare defy the regime of Big Brother; and that if something needs to be destroyed, it is undoubtedly the face of a political dissident.

Just as any authoritarian regime in Latin America "identifies national symbols with a caudillo or government" (Rojas 2008: 138), Trujillo's "megalomaniac personality led him to name (sometimes rename) a multitude of roads, plazas, schools, hospitals, bridges, cities, and even mountains after himself" (Galván 2013: 49). This personality trait pertains to the economy of facial power across a geographical area that Deleuze and Guattari term landscapity, defined as a space deterritorialized by the regime of face. "All faces envelop an unknown, unexplored landscape; all landscapes are populated by a loved or dreamed-of face" (Deleuze and Guattari 1987: 172-173). In actuality, not only was Santo Domingo "horrifyingly" named "Cuidad Trujillo" during the reign of Trujillo (Fuentes 1988: 155), but the face of Trujillo obtained its geographical ubiquity by installing some twelve hundred "monuments" of Trujillo around the capital during his hegemonic rule (Galván 2013: 50). The Feast of the Goat recounts how the names of Trujillo and his family members are displayed all over the country, with "hundreds of streets, parks, and schools" named after Trujillo's mother, known as the Sublime Matriarch (Vargas Llosa 2012: 335). With the establishment of a new government after Trujillo's assassination, President Joaquín Balaguer has to resign himself to change "Ciudad Trujillo back to Santo Domingo" and to rename "all the cities, localities, streets, squares, accidents of geography, and bridges" that were once named after the Generalissimo and his family members including his infamous sons Ramfis and Radhamés (428). In The Autumn of the Patriarch, too, the political power solidifies itself by proliferating the face of the leader via numerous mediums. As a result, the dictator's profile appears "on both sides of all coins, on postage stamps, on condom labels, on trusses and scapulars" (Garcia Marquez 2014: 4). In the dystopian world of George Orwell, totalitarian regimes possess "the ability to subjectify people and manipulate their minds through micro-level practices" rather than through "typical technologies of domination like imprisonment and corporeal torture" (Resheq and Majdoubeh 2019: 184). In Nineteen Eighty-Four, the dissemination of face is thus ensured by omnipresent portraits of Big Brother as well as by ceremonies such has Hate Day, commemorated by the barrage of "speeches, the shouting, the singing, the banners, the posters, the films, the waxworks, the rolling of drums and squealing of trumpets, the tramp of marching feet" (Orwell 1977: 180). 
The relation between face and landscape demonstrates that 'face' is not delimited to an intersubjective relation between the leader and an individual. Just as telescreens, in Nineteen Eighty-Four, are installed in every house, spying on people's activities, emotions, and even whisperings, and just as people are incessantly under the scrutiny of their own family members, working as "informers" and as the "extension of the Thought Police" (Orwell 1977: 133), an anonymous narrator in The Autumn of the Patriarch acknowledges that the General "was present in our lives as we left home, as we went to church, as we ate and as we slept" (Garcia Marquez 2014: 212-213). This ubiquity of face is tantamount to the pervasiveness of its domination across the land. This attests to the inhumanity of face, for once cast out of the regime's favour, there remains, Vargas Llosa demonstrates in his novel, no space impermeable to political harassment. Estranged Senator Cabral, as such, conceives of himself as "the living dead" (Vargas Llosa 2012: 246). He is aggressively chased by a group of SIM thugs whose mission is to discourage him from "seeking asylum" from foreign embassies (249). In a locus dominated by the dictator's face, existence is a precarious phenomenon. Trujillo confirms that Cabral "is alive, but as far as this regime is concerned, he has ceased to exist" (201). Life in Trujillo's regime is a flimsy ephemeral situation between existence and non-existence, of morphing into something in one moment and of ceasing to exist in another. The resuscitation of his life, Cabral surmises, depends solely upon the Chief's "magic" (254).

Faciality is a machine for the integration of nonconforming praxis in the same manner that troops, in Garcia Marquez's novel, orchestrate "public executions" and locate the "houses suspected of nonconformity with the regime" (Garcia Marquez 2014: 206). Nothing, The Feast of the Goat demonstrates, is constant and all depends on the degree to which a person is allowed to exist. A "higher decision" invariably holds sway over people's lives (Vargas Llosa 2012: 238). Truth is constructed by Trujillo's regime and the however reluctant or enforced consent of the people. Under this regime, it is the Goat who primarily decides what the reality is. Regarding his perilous fall from the regime's grace, Cabral has to accept a simple fact: "that for some reason you've made the Chief angry" (242). His bank accounts are "frozen" (246), and his former friends refuse to meet him or tend to be brief in their conversations with him, for his plunge into "disgrace" is thought epidemic and "infectious" (248). The papers refuse to address him as a "distinguished gentleman" and instead demote him to a mere "señor" (237). As the land becomes hostile to his existence, Cabral feels "suffocated" (252). Under Trujillo, ordinary people experience a more precarious existence. The regime's procedure is to vent its retaliation on the families of the dissidents. Salvador, one of the assassins, is well aware that the failure of the assassination plan will be ensued by "the reprisals against his sisters and brothers" (221).

Once landscape is deterritorialized by the face, the religious space, represented by the churches in the three novels, does not remain immune to atrocities. Once the Catholic Church in the Dominican Republic determines to be vociferous in its criticism of injustices committed by Trujillo's regime, the churches are no longer havens for worshippers and the clergy. Bands of "half-naked" 
prostitutes disrupt Bishop Panal's sermon and while they are publicly denouncing him for fathering their children, a group of thugs, "armed with clubs and chains", storm his church and beat "the parishioners mercilessly" (Vargas Llosa 2012: 218). Bishop Reilly, too, experiences a series of attacks. His van is detonated and his house bombarded "every night with dead animals, urine, live rats" (218). A homologous pattern is discernible in The Autumn of the Patriarch where the General's henchmen subject the Church to a variety of harassments. They storm the Apostolic Nunciature, sack "its museum of historic relics", and drag the "naked" nuncio through the streets (Garcia Marquez 2014: 121). Orwell's approach to the question of church and religion demonstrates that what happens in Nineteen EightyFour is not far from reality in Latin American types of dictatorship. Of significance is that the churches in Orwell's novel are, at most, a matter of mere reminiscence. Winston, for instance, does not recall the "church bells ringing" at all (Orwell 1977: 99). In one of his excursions in London, he encounters the picture of a familiar building which he discovers to be the church of St. Clement's, "bombed" and devastated after the Revolution (97). The other church, St. Martin's, is also utilized as a museum for "propaganda" exhibitions (99). The general rule is that all old names have to be erased and replaced by new names. History must be rewritten and hence, "anything that might throw light upon the past had been systematically altered" (98). What distinguishes Nineteen Eighty-Four from the other two novels is that the status of the Church in Oceania is systematically arrogated by the State, and Big Brother, as such, possesses the powers of both a political and a religious leader.

The entrenchment of the patriarch's faciality, in The Autumn of the Patriarch, is marked by the emergence of particular features. For instance, the despot gradually reveals the symptoms of a specific mode of oblivion, as he cannot recall whether his actual name is "Zacarias" (Garcia Marquez 2014: 109), deciding eventually to proclaim himself as "I am me" (109). This oblivion, however, is not the symptom of his senility but a crucial phase of his absolutist rule. The General's self-referential addressing, from a Deleuzo-Guattarian perspective, is a principle of the signifying regime of face according to which the despot, at his ultimate conception of authority, perceives himself as "the Face" or "supreme signifier" (Deleuze and Guattari 1987: 117). In Nineteen Eighty-Four, the face of Big Brother is the ultimate winner of the war of faces. On telescreen, people can frequently watch their country's archenemy Goldstein, "with the face of a sheep" and a "sheeplike" voice, who launches his "venomous attacks" against the doctrines of the only political party in Oceania (Orwell 1977: 12). People are also exposed to the face of his followers, resembling "Asiatic faces" who march "the endless columns of the Eurasian army" (13). The propaganda of the adversary often arouses the people's xenophobic "fear and anger" that target their foreign enemy's maliciousness (13). Yet each program that broadcasts "the hostile figure" of the adversary is eventually "melted into the face of Big Brother, black-haired, black-moustachioed, full of power and mysterious calm, and so vast that it almost filled up the screen" (15-16). Just as the face of Big Brother is the supreme face and the point of finitude for every other conceivable face on the earth, Trujillo conceives of himself as a man with 
universal superiority. He thinks his seizing of power in 1930 relieved God of the "arduous mission" of ruling a country (Vargas Llosa 2012: 266); and to examine the loyalty of the nominal president of the Republic, he asks Balaguer if he still believes "that God passed the baton to me" (267). Faciality, in the three novels, is an intertwining of a leader's conception of himself with how the majority of subjects conceive of their relation to the leader. I scrutinize this matter further in the following.

\section{The passional-paranoid face}

Religion proves to be immanent to the construction of faciality; and the three novelists demonstrate how a totalitarian system appropriates the functions of the Church. During his reign, Rafael Trujillo "adopted the official motto Dios y Trujillo (God and Trujillo), which was prominently displayed at elementary schools, public plazas, and government buildings" (Galván 2013: 49). Vargas Llosa explains that while he, as an author, was investigating the archives pertaining to the reign of Trujillo, he found the opportunity of interviewing many people: both ordinary citizens and those who were once the Chief's (that is, the dictator's) collaborators. What astonished him was that these interviewees, even several years after Trujillo's death, not only addressed the dead chief in reverential terms with "a religious kind of attitude", but one could perceive in their words the "accents" and the "atmosphere of fear" (Vargas Llosa, Boyers and Bell-Villada 2007: 220-221). What is at stake is the role of majority in the formation and solidification of dictatorship. In other words, "some" societies develop the preconditions for the composition of 'face' (Deleuze 1995: 26). This implies that the formation of faciality is not an ineluctable or an evolutionary social process, as its construction entails a mode of reciprocity between the governor and the governed, between the authority and the subject. Evoking the creation of Adam in Genesis, Garcia Marquez's novel portrays a society where everything, under the patriarch's despotic regime, is created "in his own image and likeness where space was changed and time corrected by the designs of his absolute will" (Garcia Marquez 2014: 143).

There is divinity in 'face' and thus the breach of allegiance or fealty to face incurs the wrath of regime and its apparatuses. Under the paranoid face, marriage or any emotional devotion to an unsanctioned person is a sinful relation and thus can prove disastrous, as in the case of the so-called interracial liaison between princess Diana and her Egyptian lover that terminated in their suspicious and presumably politically motivated deaths (Campbell 2017: 204). It is in this sense that in Nineteen Eighty-Four, any marriage "between Party members had to be approved by a committee appointed for the purpose" (Orwell 1977: 65). The practice intends to occlude all "loyalties" that in one way or another might vitiate the people's categorical fealty to the Party (65). The ultimate objective of the Party is to promote "a loyal willingness to say that black is white when Party discipline demands this" (212). An almost homologous pattern is delineated in The Feast of the Goat. To warn Amadito against marriage with a girl whose brother is identified as an anti-Trujillista, the Generalissimo reminds the young officer of a categorical 
parameter of his absolute will: "In my government, friends and enemies don't mix" (Vargas Llosa 2012: 38).

What is noteworthy is that "face is not a universal. It is not even that of the white man; it is White Man himself, with his broad white cheeks and the black hole of his eyes. The face is Christ" (Deleuze and Guattari 1987: 176). This dense statement regarding the intersection between face, European white man, and Christianity is more than an emphasis on the historical and political locus of face. To begin with, the above Deleuzo-Guattarian remark underscores the semiotic complexity of faciality, constructed by the intersection of two axes: despoticparanoid (or White Man) axis and authoritarian-passional (or Christ) axis. The former is constituted by endogenous forces assembled around an idea that functions as a supreme signifier with a growing circular network of people that develop, interpret, and propagate it. The latter, on the contrary, originates from a linear, almost obsessive or monomaniacal, relation to an exogenous event, a personality, or an endeavour rather than to a pivotal idea emerging from within a system (120). The two semiotic axes also correspond to two disparate types of practice: deception and betrayal. Just as deception is often a feature of despotic-paranoid regimes, betrayal usually occurs in passional-authoritarian relations in the same way that Israelites betrayed Moses, or Jesus betrayed the Jews and was himself "betrayed by Judas, the true man" (124-125).

A commixture of passional and paranoid traits is discernible in the construction of dictatorship in the three novels. In Nineteen Eighty-Four, Big Brother and the Party have arrogated to themselves the traditional position of the Church. Any praxis pertaining to the Party is considered as sacred; against this sacred state stands the profane. In other words, the polarization of sacred and profane, or the Church and the State is reversed in the world of Oceania. "The Two Minutes Hate, the daily ritual of public worship, is clearly predicated on such polarization" (Gottlieb 2007: 52). An analogous situation is predominant in both The Autumn of the Patriarch and The Feast of the Goat. Despite his inimical approach toward Christian missionary practices in his country and while accentuating that the westerners brought to the people of his country several miseries including "the Bible and syphilis" (Garcia Marquez 2014: 209), the patriarch is determined to utilize all his authoritative powers "to attain the canonization of his mother Bendición Alvarado" (118). Moreover, although he does not believe in "anything in this world or any other" (119), he insists on the authenticity of his mother's miraculous portraiture on a sheet of linen. As a result, he is enraged when the apostolic envoy testifies that the purported miraculous incident is a mere fraud and "not an act of Divine Providence" (120). Analogously, "God and Trujillo", an established motto in the Dominican Republic, testifies to the passional axis of the dictator's face. Not only does President Balaguer believes that Trujillo could not achieve success "without transcendental help" (Vargas Llosa 2012: 267), the same idea, as a doctrine, is incorporated into public education and the belief system of the masses. Trujillo is deeply intrigued by arguments that justify the "association" between him and Providence (267). In other words, the signifying machine of faciality in Nineteen Eighty-Four, The Autumn of the 
Patriarch and The Feast of the Goat represents the intersection of two axes of despotic and authoritarian in one single character. The dictators, in the three novels, are concurrently the paranoid political power as well as the beloved authoritarian power.

Passional conceptions are inherent to the formation of faciality. In Nineteen Eighty-Four, this immanent relation manifests itself when Oceania and consequently, Big Brother, are purported to be invariably in confrontation with an "absolute evil" (Orwell 1977: 34). Goldstein to whom evil powers are ascribed functions as a propaganda instrument to highlight the supernatural goodness of Big Brother as the only saviour of Oceania (Gottlieb 2007: 52). Hence, just as Goldstein or Eurasia is considered as an existential threat to Oceania, Big Brother is conceived as the One. Not only does a woman that is soothed by the image of Big Brother on the TV screen addresses him as "My Saviour" and extends "her arms toward the screen", but the people, watching the face of Big Brother on TV, chant, with some measure of religious zeal, his name as they often do "in moments of overwhelming emotion" (Orwell 1977: 16). The extent of this perception toward the dictators is also revealing in the two Latin American novels. In The Feast of the Goat, Trujillo's faciality is founded on a set of myths: "Trujillo never sweats", for he is assumed to have authority over his biological functions (Vargas Llosa 2012: 20); and only when he is alone or exercising, does he give "permission to his body to perspire" (20). The other myth which he himself believes is that he is capable of miraculous, almost messianic, deeds. Not only is he capable, similar to Jesus, to "turn water into wine and multiply loaves of bread" (19), but he also conceives of his unstable friends as "Judases" (19). During the turmoil in the wake of Trujillo's assassination, his wife has a congruous attitude toward the Dominicans: "The ingratitude of nations was a proven fact, ever since Judas' betrayal of Christ" (416). In The Autumn of the Patriarch, the religious reverence for the dictator is more vibrant. People proclaim the General "the one" and baptize their children in "his name" (Garcia Marquez 2014: 31). Religious sentiments also emerge when the lepers, the blind, and the other people with acute physical disabilities approach the General as a messianic healer and beg "the salt of health from his hands" (31). The three novels hint at the vestiges of a singular mixture of power under a dictatorship: paranoid despotism within a religious regime as well as passional authoritarianism within a despotic system.

Garcia Marquez and Vargas Llosa portray the emergence of two distinct symptoms: deception (that is a feature of despotic regimes) and betrayal (which is prevalent in passional regimes). The Autumn of the Patriarch emphasizes the intermixture of intentions under these two discrepant regimes. The officials, for instance, opt for "deceiving" the General "in order to please him" or to avoid the eruption of "useless annoyances" from him (Garcia Marquez 2014: 204). A former prostitute laments that she cannot "conceive of the world without the man" who made love to her when she was only "twelve" years old (186). The girl reassures that "no other man" can ever engender the intimacy and the "male tenderness" she experienced in her relation with the General who "ate me from head to toe with the drive and the generosity of an old man" (186). Senator Cabral, in his ruminations 
on the relation between the masses and Trujillo, not only laments the decades of "indoctrination" and brutal oppression, but also confesses the existence of devotional love for the leader: people "could worship Trujillo" (Vargas Llosa 2012: 63). The irony of dictatorship is that even the most educated people who are brought up in the western democracies allow Trujillo to abuse them "savagely" (63). This, Cabral explains, is the outcome of life under a suppressive regime where people do not "merely fear" their leader, "but love him, as children eventually love authoritarian parents, convincing themselves that the whippings and beatings are for their own good" (63).

Nineteen Eighty-Four depicts a peculiar mode of deception under despotic regimes. In the novel, the Party is intent upon the utilization of "conscious deception" (Orwell 1977: 214). Orwell conceives of this mode of delusive consciousness as "doublethink", implying the capacity of an individual to hold simultaneously two antithetical ideas in his mind; while a party member knows consciously that he is playing tricks, he is satisfied concurrently "that reality is not violated" (214). In other words, the absolutist appropriation of the Church by the State in Oceania has exterminated the border between right and wrong, truth and falsity, with the Party making people to "tell deliberate lies while genuinely believing in them" (214). It is this extermination that has rendered possible the simultaneous existence of antithetical ideas or oxymoronic mottos in people's perception of reality. It is the consequence of this total appropriation that in Nineteen Eighty-Four, unlike the other two novels, neither deception nor betrayal is possible in Oceania. Telescreens which are installed in houses and all across the city do not "let your thoughts wander" (62), for any "suggestion of abnormality", for instance, "an unconscious look of anxiety" a "muttering", a "nervous tic", an "improper expression on your face", or an "incredulous" appearance can be judged as a "punishable offence" (62).

Just as the dictators in the three novels possess the supreme face, the public are conceptually faceless. To put this another way, the minoritorian face, in a literal sense, is susceptible to being dismantled in a dictatorship. In Oceania, not only is wearing a wrong impression on one's face conceived of as "facecrime" (Orwell 1977: 62), but O'Brien also demonstrates the fragility of his victims, Winston and Julia, by showing them a cage of starving rats that "leap on to your face and bore straight into it" (285). To save his life, Winston screams "frantically" like a desperate animal, begging his torturer to "Do it to Julia! Not me! Julia!" (286). Winston conceives of Julia not only as his only true love, but also as his optimal scapegoat, the only "one person to whom he could transfer his punishment" (286). Yet whereas Nineteen Eighty-Four foresees a gloomy future for human beings under the dictatorship of Big Brother, an "all-powerful" incorporeal figure that "will never die" (Orwell 1977: 208), The Feast of the Goat and The Autumn of the Patriarch demonstrate rays of hope and change for the faceless. The audacious coconspirators, the "faceless silhouettes" engaged in Trujillo's assassination (Vargas Llosa 2012: 285), ultimately realize how one single man is behind all "the assassinations, the disappearances, the tortures, the precariousness of life, the corruption, the surrender of body, soul, and conscience" (94-95). An Orwellian 
conception of doublethink seems to be prevalent under Trujillo's regime. For his assassins are convinced that as long as Trujillo exists, multitudes of Dominicans are enforced to lead a double life: "to lie to themselves and deceive everyone else, of having to be two people in one, a public lie and a private truth that could not be expressed" (166). The Autumn of the Patriarch also depicts the final, albeit inconceivable, demise of the despot, with people realizing how the combination of complicity and compliance renders it "difficult to distinguish who was the victim of whom" (Garcia Marquez 2014: 191).

The "only condition" for survival, in The Autumn of the Patriarch, is that the officials apply their barbaric methods without disclosing their horrendous deeds to the despot (Garcia Marquez 2014: 194). In this terrifying system of subjectification, nothing remains concealed from "the invisible web of informers" (195). Whenever the machine of faciality is fully operative, the black holes function with calamitous gravity, with bestiality reaching its extreme degrees. Under such circumstances, Garcia Marquez depicts, no single soul remains unharmed from the apparatuses of suppression for which the torturers are employed not based on their certificates or recommendation letters but in regard to their voluntary resolve in tormenting their loved ones "without any change in their voice" (195). In Nineteen Eighty-Four, the two clandestine lovers, Winston and Julia, prove disloyal to each other eventually. Julia acknowledges that "they threaten you with something" you cannot endure, enforcing an individual to say, "Don't do it to me, do it to somebody else" (Orwell 1977: 292). The officials in The Feast of the Goat have to substantiate their devotion, under the threat of being demoted or even annihilated, by a "test of loyalty" (Vargas Llosa 2012: 46). For many high-ranking officials in Trujillo's era, this test involved allowing the Generalissimo to have love affairs with their wives. A substantial bulk of the novel is devoted to Urania's reminiscences of a horrifying past. As a victim of Trujillo's libertine adventurism, she recalls and explains to her relatives the traumatic experience of being offered by his father Senator Cabral to Trujillo. The love affairs, as Vargas Llosa affirms in his interview, did not result from a masochistic desire but were part of "a test to verify whether the loyalty went to the extreme of accepting that peculiar, ferocious humiliation in a machismo society" (Vargas Llosa et al. 2007: 221).

Loyalty, under dictatorship regimes, entails adherence to a specific correspondence between one's perception of reality and the recognition of authority, for a paranoid regime cannot assent to a plurality of realities. To put this another way, the yardstick of a subject's loyalty is determined by his adherence to a sanctioned version of truth. As a result, the perception of reality has, to a more or less extent, thematic significance in all the three novels. O'Brien reminds Winston that reality is a matter of mental discipline. To this high-ranking official, external or objective reality does not exist. Yet unlike the Party, the individual mind is susceptible to err. "It is impossible to see reality except by looking through the eyes of the Party" (Orwell 1977: 249). In The Autumn of the Patriarch, the reality is a constructed attitude. At times, these are the administrators who create a sanctioned version of "reality" (Garcia Marquez 2014: 90); and sometimes it is the patriarch himself who manipulates "the reins of reality" (134). An analogous approach to 
reality is discernible in The Feast of the Goat when Trujillo posits a sinister observation on the relation between him and the others. He affirms that any subject who, similar to Senator Cabral, idiotically considers himself immune to the ruling and wrath of his regime must be prescribed "a dose of reality" (Vargas Llosa 2012: 260).

The recurrence of an Orwellian dictatorship in the two novels of Latin America reveals the resistance of faciality machine against reform. Just as The Autumn of the Patriarch hints at the rise of disgruntled politicians and "postponed ambitions" after the demise of the patriarch (Garcia Marquez 2014: 142), Trujillo's death, in The Feast of the Goat, culminates in more brutality and the eradication of dissidents as if "Trujillista system continues to function of its own accord" (BellVillada 2010: 141). Nineteen Eighty-Four, with its ambience of pessimism, demonstrates the eventual defeat of any meaningful dissidence against the face of dictator. A disturbing reality, in the two Latin American novels, is that the operations of face are not confined to a mere façade of power by a single strongman, and thus the devastation of dictator's face or the possibility of deceiving, betraying, or even destroying him does not necessarily terminate its operations; nor can the destruction of face invariably occlude popular yearning for the formation of a new regime of face or dictatorship.

\section{Conclusion}

In this essay, I extensively demonstrated how Deleuze and Guattari's concept of faciality can explain the features of dictator regimes in Nineteen Eighty-Four, The Autumn of the Patriarch, and The Feast of the Goat. I probed the representation of 'face' in these novels in two interrelated sections. Under 'dictatorship of face', I explained how 'face' is proliferated, how it morphs into a quotidian reality, how it spreads across the landscape to proclaim the ubiquity of its power and norms, and how any form of nonconformity is essentially discouraged, penalized, or even eradicated. Under 'passional-paranoid face', I primarily discussed paranoid and passional axes of faciality, with each corresponding to certain forms of relation, allegiance and praxis, including deception and betrayal. What is specifically noteworthy in this respect is the intensity of a unilateral emotion between the subjects and their leaders. Dictatorships are not devoid of the vestiges of divinity and the subjects' relation to a dictator is imbued with both awe and religious zeal. The three novels demonstrate that dictator regimes are typically bent upon the appropriation of the Church or its functions.

Orwell, Garcia Marquez, and Vargas Llosa depict, to some considerable measure, that once the regime of faciality is constructed, the dictator's knowledge of the machine's operations becomes superfluous, for the construction and functioning of faciality involve not only the collaboration of a variety of apparatuses for the enforcement of loyalty to 'face', but also the passional subservience of individuals to dictatorship. In all the three novels, people are trained or expected to comply consciously with contradictory rules, arbitrary practices, or any dictated mode of reality. Life under such regimes is devoid of any meaningful stability and no more than a precarious moment between existence and non- 
existence. This also implies that the formation of a dictatorship demands not only religious devotion but also a substantial measure of religious authoritarianism. The triumph of faciality is an appalling aspect of the dictator regime in Nineteen EightyFour. To some limited measure, both The Feast of the Goat and The Autumn of the Patriarch analogously hint at those processes that trigger the formation and perpetuation of face. Just as Vargas Llosa recounts the continued use of torture and oppression in the wake of Trujillo's assassination, Garcia Marquez tangentially cautions us against the procrastinated ambitions for power that may foment the rise of another nightmarish reign of face for an indefinite period.

Mohammad Safaei

School of English

University of Nottingham, Malaysia

Email: safaeim@hotmail.com 


\section{References}

Bell, Michael. (1993). Gabriel Garcia Marquez: Solitude and Solidarity. New York: Macmillan.

Bell-Villada, Gene H. (2010). 'Sex, politics, and high art: Vargas Llosa's long road to the feast of the goat'. In Juan E. De Castro and Nicholas Birns (eds.), Vargas Llosa and Latin American Politics, 139-157. New York: Palgrave Macmillan.

Boldy, Steven. (2010). 'The autumn of the patriarch'. In Philip Swanson (ed.), The Cambridge Companion to Gabriel Garcia Marquez, 78-93. Cambridge: CUP.

Campbell, Charles. (2017). 'Reading the veil of imperial discourse: Shakespeare and Arab-English accounts of the death of Diana.' International Journal of Arabic-English Studies, 17: 203-216.

Deleuze, Gilles. (1995). Negotiations: 1972-1990. Trans. Martin Joughin. New York: Columbia UP.

Deleuze, Gilles. (2003). Francis Bacon: The Logic of Sensation. Trans. Daniel W. Smith. London: Continuum.

Deleuze, Gilles and Claire Parnet. (2007). Dialogues II. Trans. Hugh Tomlinson and Barbara Habberjam. New York: Columbia UP.

Deleuze, Gilles and Félix Guattari. (1987). A Thousand Plateaus: Capitalism and Schizophrenia. Trans. Brian Massumi. Minneapolis: University of Minnesota Press.

Donoso, José. (1977). The Boom in Spanish American Literature: A Personal History. Trans. Gregory Kolovakos. New York: Columbia UP.

Dosse, François. (2010). Gilles Deleuze and Félix Guattari: Intersecting Lives. Trans. Deborah Glassman. New York: Columbia UP.

Figueroa, Víctor. (2013). 'Disseminating el chivo: Junot Díaz's response to Mario Vargas Llosa in the brief wondrous life of Oscar Wao'. Chasqui: revista de literatura latinoamericana, 42 (1): 95-108.

Fuentes, Carlos. (1988). 'Discovering Mexico'. The Wilson Quarterly, 12 (4): 148-159.

Galván, Javier A. (2013). Latin American Dictators of the 20th Century: The Lives and Regimes of 15 Rulers. Jefferson, NC: McFarland.

Garcia Marquez, Gabriel. (2014). The Autumn of the Patriarch. Trans. Gregory Rabassa. London: Penguin.

Gottlieb, Erika. (2007). 'The demonic world of Oceania: The mystical adulation of the sacred leader'. In Harold Bloom (ed.), Bloom 's Modern Critical Interpretations: George Orwell's 1984, 51-69. New York: Chelsea House.

Griffin, Clive. (2012). 'The dictator novel: The feast of the goat'. In Efraín Kristal and John King (eds.), The Cambridge Companion to Vargas Llosa, 116-128. Cambridge: CUP. 
Guattari, Félix. (2011). The Machinic Unconscious: Essays in Schizoanalysis. Trans. Taylor Adkins. Los Angeles, CA: Semiotext(e).

Guattari, Félix. (2016). Lines of Flight: For another World of Possibilities. Trans. Andrew Goffey. London: Bloomsbury.

Ingle, Stephen. (2006). The Social and Political Thought of George Orwell: A Reassessment. London: Routledge.

Lonoff, Sue. (2007). 'Composing Nineteen Eighty-Four: The art of nightmare'. In Harold Bloom (ed.), Bloom's Modern Critical Interpretations: George Orwell's 1984, 31-50. New York: Chelsea House.

López-Calvo, Ignacio. (2005). God and Trujillo: Literary and Cultural Representations of the Dominican Dictator. Gainesville, FL: University Press of Florida.

Marks, Peter. (2011). George Orwell the Essayist: Literature, Politics and the Periodical Culture. London: Bloomsbury Academic.

Martin, Gerald. (2008). Gabriel Garcia Marquez: A Life. New York: Vintage Books.

Moraña, Mabel. (2016). Arguedas / Vargas Llosa: Dilemmas and Assemblages. Trans. Andrew Ascherl. New York: Palgrave Macmillan.

Orwell, George. (1977). Nineteen Eighty-Four. New York: Signet Classics.

Pelayo, Rubén. (2009). Gabriel Garcia Marquez: A Biography. Westport, CT: Greenwood Press.

Plank, Robert. (2007). 'The ghostly bells of London'. In Harold Bloom (ed.), Bloom's Modern Critical Interpretations: George Orwell's 1984, 83-92. New York: Chelsea House.

Polit-Dueñas, Gabriela. (2007). 'Same old story: On women, caudillos, and literature in la fiesta del chivo'. Letras Femeninas, 33 (2): 99-119.

Resheq, Reem and Ahmad Y. Majdoubeh. (2019). 'Critical dystopia: Local narrative in the threshold in Ahmed Khaled Towfik's Utopia'. International Journal of Arabic-English Studies, 19 (1): 175-194.

Rojas, Rafael. (2008). Essays in Cuban Intellectual History. New York: Palgrave Macmillan.

Rossi, John and John Rodden. (2007). 'A political writer'. In John Rodden (ed.), The Cambridge Companion to George Orwell, 1-11. Cambridge: CUP.

Sabin, Margery. (2007). 'The truths of experience: Orwell's nonfiction of the 1930s'. In John Rodden (ed.), The Cambridge Companion to George Orwell, 43-58. Cambridge: CUP.

Trilling, Diana. (1975). 'Nation'. In Jeffrey Meyers (ed.), George Orwell: The Critical Heritage, 259-261. London: Routledge.

Vargas Llosa, Mario. (2010). In Praise of Reading and Fiction: The Nobel Lecture. Trans. Edith Grossman. New York: Farrar, Straus \& Giroux.

Vargas Llosa, Mario. (2012). The Feast of the Goat. Trans. Edith Grossman. London: Faber \& Faber.

Vargas Llosa, Mario, Robert Boyers and Gene H. Bell-Villada. (2007). 
'Exhilaration and completeness: An interview with Mario Vargas Llosa'. Salmagundi, 155/156: 212-240.

Williams, Raymond. (2007). 'Afterword: Nineteen eighty-four in 1984'. In Harold Bloom (ed.), Bloom's Modern Critical Interpretations: George Orwell's 1984, 9-30. New York: Chelsea House.

Williams, Raymond L. (2007). 'The autumn of the patriarch'. In Harold Bloom (ed.), Bloom's Modern Critical Views: Gabriel Garcia Marquez, 123-144. New York: Chelsea House. 